\title{
The problems of COVID-19 waste management in East Java
}

\author{
A. Tanjung*, A. Kodir, I.K. Astina, M.Y. Affandi \& M.G. Rosyendra \\ Universitas Negeri Malang, Malang City, Indonesia
}

\begin{abstract}
The increase in the number of positive COVID-19 patients in Indonesia shows that the Indonesian government has not been fully prepared to face this outbreak. As a consequence, there has been an increase in COVID-19 medical waste. This study aims to explain how the management of COVID-19 medical waste has been handled properly or not. In addition, this study aims to explain whether the government has prepared special efforts to overcome this problem. This research was conducted in the East Java region. This study used qualitative research methods. The data collection process was carried out through semi-structured interviews with several relevant stakeholders. The results of this study indicate that medical waste management in East Java, especially in Surabaya, has not been optimally realized. This is due to the availability of infrastructure, funding, strict licensing, and the low human resource capacity for medical waste management.
\end{abstract}

Keywords: COVID-19, Medical Waste, Management, East Java.

\section{INTRODUCTION}

The increase in the number of COVID-19 patients in East Java ranks 2nd in Indonesia. This shows that the East Java provincial government is not yet fully prepared to face this outbreak. To date, there are 37,839 positive patients treated in all hospitals in East Java (Task Force for the Acceleration of Handling COVID-19, 2020). As a consequence, there is an increase in the amount of medical waste COVID-19. The waste produced by COVID-19 is a class of infectious waste that can transmit disease if special handling is not done (Yu et al. 2020).

It is easy to spread COVID-19 through medical devices that have been used to treat COVID-19 patients. The use of single-use PPE (Personal Protective Equipment) to treat COVID 19 patients and maintain the safety of health workers is considered able to increase the amount of medical waste produced (Saadat et al. 2020). So, it can be assumed that a logical comparison of the amount of PPE waste produced is directly proportional to the amount of PPE needed to handle one COVID-19 patient until they are cured.

PPE and B3/medical waste management has not been carried out optimally. This is evidenced by the occurrence of several cases related to waste disposal, one of which was at the Surabaya Acne Babat public cemetery by health officials on June 27, 2020 (Davina 2020). This careless disposal of PPE waste shows the weakness of supervision regarding medical waste management. A study shows that COVID-19 can survive on plastic and metal objects for 2-3 days (Peng et al. 2020). This condition raises concerns in the surrounding community regarding the transmission of COVID- 19 .

The impact of medical waste can affect the environment. Improper disposal of B3/medical waste poses serious risks to public health and the environment (Ilyas et al. 2020). In addition, according to Ghayebzadeh (in Kargar et al. 2020) B3/medical COVID-19 waste is dominated by plastic base materials and can threaten the environment if disposed of without further management. However, given the limited infrastructure, funding, and low awareness, the increase in the generation of PPE and $\mathrm{B} 3 /$ medical waste needs to be prioritized and requires special attention and handling.

\footnotetext{
*Corresponding author: ardyanto.tanjung.fis@um.ac.id
} 


\section{METHODS}

This research used qualitative research methods. The data collection process was carried out in several stages, namely determining the study area, interview, discussion forum, observation and literature study. The interview process was carried out in-depth and semi-structured to several relevant stakeholders. Interviews were conducted in person and by telephone, given the limited access to some areas. Meanwhile, a focused discussion process was carried out with several local communities who took the initiative to make efforts to handle COVID-19 waste. Some of the informants who will be interviewed include the East Java Province COVID-19 Task Force Team, the East Java Provincial Health Office, the East Java Provincial Environmental Service, East Java WALHI, the ITB Environmental Engineering Alumni Association (IATL ITB), Bappenas, PT. Medifast Services and Indonesian Hospital Association (PERSI).

The data analysis instrument is adapted to qualitative methods where the meaning of findings or facts about complex phenomena on the relationships and patterns and configurations between factors. Investigations and evidence of COVID-19 medical waste treatment consisted of the availability of a sanitation unit responsible for Health Care Waste Management (HCWM), HCWM design, HCWM guidelines, waste separation practices, and HCWM technology used by the surveyed hospitals. This fact is a predetermined estimate of the need for health services and the population.

\section{RESULTS AND DISCUSSION}

Based on data from the Ministry of Health, the number of COVID-19 patients experiencing a graph of increase every day was recorded as of August 31 as being 37,839 in East Java (Task Force for the Acceleration of Handling COVID-19 2020). Based on the data above, there are around 100 hospitals that are used as a reference for handling COVID-19 patients, which can produce a large amount of medical waste along with the increasing trend in the number of COVID-19 patients. As recorded in the 2019 East Java Province Medical Hazardous Waste Inventory and Management Study, the total number of B3/Medical waste piles from 38 Hospitals in Regencies and Cities in East Java were 15,745.94 Kg/day and 5,747.27 Tons/day (Dinas Lingkungan Hidup JawaTimur 2020).

The pile of B3/Medical waste that has accumulated indicates the need for action in good waste management. Management of medical waste from health facilities prior to the pandemic is regulated in the Minister of Environment and Forestry Regulation 56/2015 Procedures and Technical Requirements for Management of Hazardous and Toxic Waste from Health Service Facilities (Bappenas dan Ikatan Alumni Teknik Lingkungan 2020). The regulation describes the stages of waste management starting from reduction and sorting, container and storage, transportation, processing, burial and landfilling. In 2018 the Directorate for Performance Assessment of Hazardous and Non-B3 Waste Management of the Ministry of Environment and Forestry also issued a roadmap related to waste management from health facilities from 2019 to 2028. This is also regulated in Permenkes 7/2019 concerning Home Environmental Health Sick.

In the flow of health facilities medical waste management, this becomes a concern for the environment because B3/medical waste is not handled properly. This can lead to new problems such as the emergence of diseases and environmental damage caused by pollution, so there is a need for serious handling of B3/Medical waste (Saadat et al. 2020). Referring to the Circular of the Minister of Environment for 2020 SE.2 / MENLHK / PLB.3 / 3/2020, the tools used for handling $\mathrm{B} 3 /$ Medical waste are incinerators and autoclaves. However, it does not mean that the incinerator and autoclave tools listed in the Ministerial Regulation can be used just like that, but there are strict regulations in the use of these tools. This is what causes not all hospitals/health care facilities in East Java to have an incinerator due to licensing constraints.

Based on the results of interviews with the Environmental Agency of East Java Province in East Java, the number of hospitals is around 133 units, but only 26 hospitals have medical waste 
treatment equipment with a thermal method (incinerator) with an operating license. This is a gap when all hospitals can produce waste which is increasing in quantity during the COVID19 pandemic. However, the amount of utilization of medical waste processing equipment is still insufficient (Bappenas dan Ikatan Alumni Teknik Lingkungan 2020). The city of Surabaya was designated by the Ministry of Health as the Black Zone because it is the largest contributor to positive COVID-19 patients in East Java (Sunuantari \& Zarkasi 2020). In the data recapitulation of medical waste generation in East Java in 2019 by DLH, Surabaya City holds the first position with the highest number of medical waste generation with a total of 2,060, 92 tons/year from a total of 5,747.27 tons/year (Dinas Lingkungan Hidup Provinsi Jawa Timur, 2020). Seeing the amount of medical waste produced and the number of hospitals that have licensed incinerators cross, this is an opportunity for third parties to cooperate. However, third parties cooperating with hospitals that do not have a responsibility to manage waste must be in accordance with regulations from the Government, the Ministry of Health, the Environmental Service, and related agencies.

Based on the results of interviews with the Indonesian Hospital Association (PERSI) and the Environmental Service of East Java Province, it was stated that the procurement of medical waste processing equipment had obstacles, including the procurement cost factor, the human resource factor and managing equipment operation permits. In terms of cost factors when referring to PP. No. 101 of 2014 concerning Hazardous Waste Management, the construction of an incinerator tool must be in accordance with the standards, with a chimney height of at least $14 \mathrm{~m}$ from the ground. Operating costs of the incinerator, equipment maintenance costs and medical waste management costs are often large. The human resource factor in question is the inadequate knowledge of medical waste managers in understanding the good management standards that have been set by the relevant agencies. Finally, related to licensing, in carrying out permits/licensing extensions to operate the incinerator tool, it takes a long time and the criteria that must be met by the agency (hospital) are strict as stated in the legal basis for infectious waste management.

\section{CONCLUSION}

In summary, COVID-19 cases and victims who die from the pandemic in East Java continue to increase every day. The Indonesian government and the regions were not responsive enough to respond to the COVID-19 pandemic until it was finally declared a national disaster. The increase in the amount of B3/medical COVID-19 waste is a new problem during this pandemic. Medical waste management in East Java, especially in Surabaya, has not been implemented optimally. This is due to the availability of infrastructure, funding, strict licensing and the low human resource capacity for medical waste management. Therefore, special attention is needed regarding the management of B3/medical COVID-19 waste.

\section{REFERENCES}

Bappenas dan Ikatan Alumni Teknik Lingkungan, I. T. B. (IATL I. (2020) Pengelolaan Limbah B3 Medis dan Sampah Rumah Tangga Penanganan COVID-19.

Davina, D. (2020) 'Limbah APD Berserakan Di Pemakaman, Pemkot Surabaya: Bukan Milik Petugas Makam', Kompas TV. Available at: https://www.kompas.tv/article/90444/limbah-apd-berserakan-di-pemakamanpemkot-surabaya-bukan-milik-petugas-makam.

Dinas Lingkungan Hidup Provinsi Jawa Timu (2020) 'Pengelolaan Limbah B3 Medis Pada Masa Pandemi COVID-19'.

Ilyas, S., Srivastava, R. R. and Kim, H. (2020) 'Disinfection technology and strategies for COVID-19 hospital and bio-medical waste management', Science of the Total Environment, 749, p. 141652. doi: 10.1016/j.scitotenv.2020.141652.

Kargar, S., Pourmehdi, M. and Paydar, M. M. (2020) 'Reverse logistics network design for medical waste management in the epidemic outbreak of the novel coronavirus (COVID-19)', Science of the Total Environment, 746, p. 141183. doi: 10.1016/j.scitotenv.2020.141183. 
Peng, J. et al. (2020) 'Medical waste management practice during the 2019-2020 novel coronavirus pandemic: Experience in a general hospital', American Journal of Infection Control, 48(8), pp. 918-921. doi: 10.1016/j.ajic.2020.05.035.

Saadat, S., Rawtani, D. and Hussain, C. M. (2020) 'Environmental perspective of COVID-19', Science of the Total Environment. Elsevier B.V., p. 138870. doi: 10.1016/j.scitotenv.2020.138870.

Sunuantari, M. and Zarkasi, I. R. (2020) 'Tata kelola black zone COVID-19 berbasis komunitas'.

Yu, H. et al. (2020) 'Reverse Logistics Network Design for Effective Management of Medical Waste in Epidemic Outbreaks: Insights from the Coronavirus Disease 2019 (COVID-19) Outbreak in Wuhan (China)', International Journal of Environmental Research and Public Health, 17(5), p. 1770. doi: 10.3390/ijerph17051770. 